\title{
ПРОЕКТ «КРИМ.РЕАЛІЇ» УКРАЇНСЬКОЇ РЕДАКЦІЇ РАДІО «СВОБОДА»: ІНФОРМАЦІЙНИЙ СПРОТИВ РОСІЙСЬКІЙ АНЕКСІЇ ПІВОСТРОВА
}

\author{
Іван Ципердюк \\ ПВНЗ «Університет Короля Данила», \\ вул. С. Коновальия, 35, 76018, Івано-Франківськ, Украӥна \\ e-mail: zdjuk@ukr.net \\ https://orcid.org/0000-0003-0940-5066
}

У статті простежено історію створення проєкту «Крим.Реалії» української редакції радіо «Свобода» як відповідь на російську анексію півострова. Продемонстровано, що проєкт «Крим.Реалії» основним напрямком своєї роботи обрав поширення незалежної інформації та протистояння російській пропаганді. 3'ясовано, що, незважаючи на переслідування з боку окупаційної влади, журналісти проєкту продовжують працювати в Криму, повідомляючи правдиву інформацію про ситуацію на півострові. Показано, що діяльність проєкту також спрямована на налагодження комунікації з населенням окупованої території та підтримку впевненості кримців, що півострів у майбутньому повернеться до складу української держави.

Ключові слова: «Крим.Реалії», українська редакція радіо «Свобода», анексія, російська пропаганда, окупація.

1. Постановка проблеми. Російська анексія Криму в лютому-березні 2014 року показала повну не лише військову, але й інформаційну беззахисність українського півострова. Масштабному пропагандистському зомбуванню російських ЗМІ фактично не було кому протистояти з українського боку. Така ситуація склалася не випадково, вона була результатом ретельної, багатолітньої інформаційно-пропагандистської операції, яку Росія послідовно проводила в Криму. Безпосереднім наслідком злочинної бездіяльності української влади стало старанне уникання аналізу, вирішення та запобігання проблемам, які виникали внаслідок багаторічних провокаційних дій Російської Федерації. Головний редактор проєкту «Крим.Реалії» В. Притула вважає, що навіть в період до окупації півострова не було відповідного розуміння реалій з боку України: «Мало хто знає, що відбувалося на півострові навіть до 2013 року. У мене взагалі таке враження, що в Україні мало хто цікавився не тільки Кримом...»1. Як

\footnotetext{
1 Зінченко-Апостолова, Л. (2017), «Журналісти «Крим.Реалї»: Ми відчуваємо тиск - $i$ з боку українського суспільства, $і$ з боку окупаційної влади Криму», Detektor.Media, доступно за адресою URL: https://detector.media/infospace/article/128485/2017-07-31-zhurnalisti-krim-realii-mividchuvaemo-tisk-i-z-boku-ukrainskogo-suspilstva-i-z-boku-okupatsiinoi-vladi-krimu/ (дата перегляду 6 листопада 2019 р.).

(C) Ципердюк I., 2020
} 
наслідок - інформаційну оборону Криму від агресора довелося організовувати, докладаючи надзусиль в умовах постійних переслідувань та загрози суворих покарань.

Актуальність наукової розвідки полягає у висвітленні особливостей створення проєкту «Крим.Реалії» української редакції радіо «Свобода», який став головним інформаційним ресурсом, що об'єктивно повідомляє аудиторію про події в Криму, Україні та світі, на відміну від російських пропагандистських 3МI.

Метою статті є комплексний аналіз проєкту «Крим.Реалії» української редакції радіо «Свобода». Завдання дослідження - показати, за яких історичних обставин створювався цей проєкт, простежити віхи його становлення та значення для утримування громади півострова в українському інформаційному полі.

2. Теоретичне підгрунтя. Питання, пов'язані з історією створення проєкту «Крим. Реалії», переважно розглядали у своїх статтях журналісти: Ю. Луканов², I. Кузнєцова ${ }^{3}$, В. Портников ${ }^{4}$, В. Притула ${ }^{5}$ та ін. Зважаючи на те що цьому проекту української редакції радіо «Свобода» лише п’ять років, науковці поки що не встигли приділити цій темі належної уваги. Без сумніву, назріла потреба звернутися до розгляду та аналізу цього питання, зважаючи на важливість роботи, яку здійснює проєкт «Крим.Реалії» для розширення та посилення українського медіапростору на тлі російської військової та інформаційної агресії.

3. Методологічна основа дослідження. У роботі використано методи аналізу та синтезу, а також моніторингу публікацій за темою. Узагальнення та розгляд усіх обставин та фактів, які супроводжували створення проєкту «Крим.Реалії» української редакції радіо «Свобода», дали змогу, спираючись на згадані методи, зрозуміти своєчасність та важливість такого кроку в умовах російської окупації півострова.

4. Виклад основного матеріалу дослідження. Революція гідності яскраво підтвердила прагнення українського народу належати до європейського співтовариства. Криваві події на київському Майдані продемонстрували, яку високу ціну готові заплатити українці за свій цивілізаційний вибір.

Збереження курсу на євроінтеграцію, небажання перебувати в статусі колонії північного сусіда детонували масштабну військово-інформаційну агресію з боку Роciї, яка беззастережно сприймала Україну як зону свого історичного впливу.

Першим кроком стала анексія Криму. У лютому 2014 р., одразу після Євромайдану, на півострові з'явилися «зелені чоловічки» - озброєні російські військові, які, однак, не мали жодних розпізнавальних знаків. Грунт для їхнього приходу був підготовлений роками російської пропаганди, проведенням численних проросійських громадських акцій, зібрань і мітингів: «Величезну роль у цій ганебній операції зі-

2 Луканов, Ю. (2018), Пресувальна машина: як Росія знищувала свободу слова в Криму, Київ, КБЦ, $176 \mathrm{c}$.

3 Холоденко, О. (2019), Мені погано, коли мовчу. Журналістика незалежної України: інтерв'ю відомих медійників, Київ, Паливода А. В., 512 с.

4 Портников, В. (2017), «Український Крим і гра Кремля в «іноземних агентів», Detektor.Media, доступно за адресою URL: https://detector.media/withoutsection/article/132099/2017-11-19ukrainskii-krim-i-gra-kremlya-v-inozemnikh-agentiv/ (дата перегляду 6 листопада 2019 p.).

5 Толокольнікова, К. (2016), «Володимир Притула: Жоден кримський журналіст не пише для «Крым.Реалии» під власним іменем», Detektor.Media, доступно за адресою URL: https://detector. media/community/article/114325/2016-04-14-volodimir-pritula-zhoden-krimskii-zhurnalist-ne-pishedlya-krym-realii-pid-vlasnim-imenem/ (дата перегляду 6 листопада 2019 р.). 
грали підконтрольні Кремлю російські засоби масової інформації, які цілеспрямовано працювали не один рік, промиваючи мозок не лише мешканцям півострова, а й усім українцям» ${ }^{6}$.

Журналісти, які намагалися чесно висвітлювати ці драматичні події, зазнавали переслідувань, до них окупаційна влада та проросійські активісти виявляли неприховану агресію та ворожість, часто застосовували насильство. Проти України на повну потужність запрацювала російська пропагандистська машина тотальної дезінформації: «Ілья Кізіров (зараз журналіст російської редакції радіо «Свобода»I. Ц.) описав свого часу п’ятничні редакційні наради в Кремлі, які найчастіше проводить Дмітрій Песков. Кізіров наводить слова одного з топ-менеджерів після анексії Криму: «Зараз не час шукати істину. Наша країна повернулася до холодної війни». Він згадує про той період своєї роботи так: «На стіні нашого центрального ньюзруму був прикріплений папірець із написом: «Крим: не “анексія”, а “возз'єднання"». Це були терміни, які повинні були застосовувати ведучі та журналісти для висвітлення анексії Криму. 3 нашої студії ми навчали всю країну цілковито новому словнику: “хунта” (український уряд), “м’ясники” (українська армія), “п’ята колона” (російська опозиція)»7.

Не натрапивши на жоден інший опір, російські агресори та місцеві колаборанти дуже швидко усвідомили, що їхнім головним ворогом залишаються лише незалежні масмедіа. Основною метою окупантів стала їхня ліквідація або ж повне підпорядкування: «Що найперше зробила російська влада, коли прийшла в Крим? Заборонила українські телеканали, викинула альтернативні джерела інформації - ATR, «Чорноморку», всі хороші видання. Тобто ускладнила будь-який доступ людей до альтернативної інформації. Цю блокаду треба прорвати» ${ }^{8}$. Таке рішення, яке озвучив тодішній кореспондент української редакції радіо «Свобода», а згодом редактор проєкту «Крим.Реалії» В. Притула, стало відповіддю на свавільні дії окупаційної влади.

Ще до початку проєкту, напередодні проведення «псевдореферендуму» за від’єднання Криму, на півострів приїжджали журналісти української редакції радіо «Свобода» Л. Стек, А. Дубчак, Ж. Безп’ятчук. Вони фіксували блокування українських військових частин, проросійські мітинги, появу «зелених чоловічків» та ін. Після того, як Л. Стека під час зйомок блокування військової частини схопили «зелені чоловічки» і в кайданках, з мішком на голові вивезли в поле (за кілька годин відпустили), стало зрозуміло, що «свободівцям» у Криму працювати небезпечно для життя9.

Традиційна редакційна політика української редакції радіо «Свобода» - надавати аудиторії те, що недоступно для неї в місцевих ЗМІ: відверте обговорення різних тем, новини без цензури, можливість інтерактивного спілкування. Така позиція

6 Луканов, Ю. (2018), Пресувальна машина: як Росія знищувала свободу слова в Криму, Київ, КБЦ, c. 12.

7 Почепцов, Г. (2019), (Дез)информация, Киев, Паливода А. В., с. 19.

8 Толокольнікова, К. (2016), «Володимир Притула: Жоден кримський журналіст не пише для «Крым.Реалии» під власним іменем», Detektor.Media, доступно за адресою URL: https://detector. media/community/article/114325/2016-04-14-volodimir-pritula-zhoden-krimskii-zhurnalist-ne-pishedlya-krym-realii-pid-vlasnim-imenem/ (дата перегляду 6 листопада 2019 р.).

9 Холоденко, О. (2019), Мені погано, коли мовчу. Журналістика незалежної України: інтервюю відомих медійників, Київ, Паливода А. В., с. 219-220. 
радіо «Свобода» повністю суперечила вихолощенню окупантами інформаційного поля в Криму: «На півострові тепер страшенна цензура та обмеження на отримання інформації як у традиційних медіа - на телебаченні, радіо, в газетах, так і в інтернеті. Все це під контролем російської влади й спецслужб» ${ }^{10}$.

Перший російськомовний сайт проєкту «Крим.Реалії» розпочав роботу 25 березня 2014 р., сайти українською та кримськотатарською мовами - на початку квітня цього ж року: «Створення проєкту «Крим.Реалії» стало відповіддю корпорації на анексію та окупацію Криму Росією. Адже місія «Радіо Свобода» - доносити інформацію тим людям і на ті території, де є обмеження свободи слова. Тож щойно ми побачили, що в Криму журналістам важко працювати, взялися за цей проєкт. Вже тоді, в березні 2014-го, відчувався тиск із боку «самооборони Криму», проросійських сил, були погрози, затримання, побиття медійників»" .

Уже до грудня 2014 р., лише за кілька місяців роботи проєкту «Крим.Реалії» на півострові, через постійні переслідування та погрози з боку російських спецслужб та проросійських активістів редакції довелося спершу переїхати до Херсонської області, а згодом - до Києва. Об’єктивне висвітлення подій у Криму стало основною причиною постійного, тотального переслідування журналістів редакції «Крим.Реалії»: «“Самооборона” або працівники ФСБ просто казали журналістам: «Чого тримаєшся за «Крим.Реалії»? Вийдеш з дому і не повернешся». Для багатьох це було важко, бо журналісти постійно відчували стеження. Практично всі, хто працював 3 нами на першому етапі, виїхали, решта - не можуть працювати відкрито» ${ }^{12}$. Показовим у цьому сенсі стало кримінальне переслідування ветерана кримської української журналістики Миколи Семени за публікацію колонки на сайті «Крим.Реалії». Журналістові пенсійного віку окупанти інкримінували заклик до порушення територіальної цілісності Росії з використанням ЗМІ. Коментуючи порушення кримінальної справи щодо журналіста, голова окупаційної Держради Криму В. Костантінов заявив, що діяльність журналістів «Крим.Реалії»є ворожою щодо Росії: «Я цих людей добре знаю. Це наші вороги. Вони вороги Росії, вороги Криму. I що б вони не написали, мета у них одна - зробити нам боляче, зробити нам погано. Нічого спільного зі свободою слова це не має взагалі. Ніякої там свободи немає. Там йде одна брехня. Оплачують все західні спецслужби з однією метою - заподіяти шкоду Росії. Що б ми не робили, вони все одно будуть шукати якусь гидоту» ${ }^{13}$. Як наслідок -22 вересня 2017 p. М. Семена отримав вирок, який передбачав два 3 половиною роки позбавлення волі умовно і три роки заборони на професійну діяльність.

\footnotetext{
${ }_{10}$ Толокольнікова, К. (2016), «Володимир Притула: Жоден кримський журналіст не пише для «Kрым.Реалии» під власним іменем», Detektor.Media, доступно за адресою URL: https://detector. media/community/article/114325/2016-04-14-volodimir-pritula-zhoden-krimskii-zhurnalist-ne-pishedlya-krym-realii-pid-vlasnim-imenem/ (дата перегляду 6 листопада 2019 р.).

11 Там само.

12 Зінченко-Апостолова, Л. (2017), «Журналісти «Крим.Реалії»: Ми відчуваємо тиск - і з боку українського суспільства, і з боку окупаційної влади Криму», Detektor.Media, доступно за адресою URL: https://detector.media/infospace/article/128485/2017-07-31-zhurnalisti-krim-realii-mividchuvaemo-tisk-i-z-boku-ukrainskogo-suspilstva-i-z-boku-okupatsiinoi-vladi-krimu/ (дата перегляду 6 листопада 2019 р.).

13 «Константинов про «Крим.Реалії». Це вороги, які хочуть зробити боляче» (2016), Украӥнська правда, доступно за адресою URL: https://www.pravda.com.ua/news/2016/04/20/7106176/ (дата перегляду 6 листопада 2019 р.).
} 
Численні кримські ЗМІ, які впродовж 2014 р. вже повністю контролював Кремль, чинили постійні обструкції діяльності проєкту «Крим.Реалії». У такий спосіб російська окупаційна влада, спираючись на допомогу місцевих колаборантів, у кращих традиціях радянської пропаганди часів холодної війни намагалася створити з редакції «Крим.Реалії» образ ворога. Журналісти, задіяні в проєкті, намагаються лише доносити до аудиторії в Криму об'єктивну інформацію про реальний стан справ, наголошуючи: «Ми не $\epsilon$ пропагандистським ресурсом і не можемо займатися пропагандою. Ми не $є$ ресурсом, який своєю метою ставить повернення Криму. Місія «Радіо Свобода» (а «Крим.Реалії» є частиною цієї міжнародної медіакомпанії) - це поширення альтернативної, вільної інформації для таких регіонів, що мають проблеми зі свободою слова. Ми даємо інформацію - і про хороші події, і про погані»» ${ }^{14}$. Однак дотримання загальновизнаних журналістських стандартів, виявляється, цілком достатньо, аби бути зарахованим до числа «ворогів Росії».

У вересні 2015 р. команда проєкту запустила радіо «Крим.Реалії», яке транслює свої програми на середніх хвилях 549 АМ на більшість території півострова, південний схід України та передгірські райони Північного Кавказу. А вже у квітні 2016 р. тодішній «прокурор» Криму Н. Поклонська заявила, що готує відповідні документи для повного блокування сайту «Крим.Реалії» - підрозділу української редакції радіо «Свобода». У повідомленні «прокуратури» стосовно цього було наголошено: «Аналіз контенту цього ресурсу свідчить про його спрямованість на дискредитацію діяльності Російської Федерації на території Республіки Крим, розпалюванні міжнаціональної ворожнечі, а також про здійснення закликів до екстремістської діяльності» ${ }^{15}$.

4 вересня 2017 р. радіо «Крим.Реалії» також розпочало мовлення на частоті 105,9 FM, сигнал іде з Чонгара на півдні Херсонської області. Програми радіо «Крим. Реалії» 24 години на добу українською та російською мовами в якісному звучанні дістали змогу почути мешканці північного та східного Криму.

Початок мовлення радіо «Крим.Реалії» та інших українських медіа з Чонгару викликав бурхливу реакцію з боку окупаційної адміністрації. Так званий «міністр внутрішньої політики, інформації та зв'язку Криму» Д. Полонський одразу ж заявив, що мовлення українських ЗМІ на територію Криму буде припинено як таке, що «не відповідає «російському законодавству». Підконтрольний Кремлю «глава» Криму С. Аксьонов запропонував увімкнути «пісні воєнних років», щоби глушити радіосигнал 3 українського боку за прикладом КНДР. Член Національної ради з питань телебачення та радіомовлення України С. Костинський у відповідь на заяви колаборантів зауважив, що окупаційній владі не вдасться заглушити українське мовлення в Кримуㅎ․

\footnotetext{
14 Зінченко-Апостолова, Л. (2017), «Журналісти «Крим.Реалї̈»: Ми відууваємо тиск - $i$ з боку українського суспільства, $і$ з боку окупаційної влади Криму», Detektor.Media, доступно за адресою URL: https://detector.media/infospace/article/128485/2017-07-31-zhurnalisti-krim-realii-mividchuvaemo-tisk-i-z-boku-ukrainskogo-suspilstva-i-z-boku-okupatsiinoi-vladi-krimu/ (дата перегляду 6 листопада 2019 р.).

15 «Прокуратура окупованого Криму зібралася повністю заблокувати сайт «Крим.Реалї̈, (2016), Тиждень.uа, доступно за адресою URL: https://tyzhden.ua/News/163403 (дата перегляду 6 листопада 2019 р.).

16 «3 квітня в окупованому Росією Криму можна буде слухати чотири українські радіостаниії», (2017), Detektor.Media, доступно за адресою URL: https://detector.media/infospace/ article/123794/2017-03-05-z-kvitnya-v-okupovanomu-rosieyu-krimu-mozhna-bude-slukhati-chotiriukrainski-radiostantsii/ (дата перегляду 6 листопада 2019 р.).
} 
Показовим є факт, що в другій половині 2017 р. російська інформаційно-аналітична система «Медиалогия» опублікувала рейтинг ЗМІ анексованого півострова, згідно з яким сайт «Крим.Реалії» увійшов до трійки лідерів за цитуванням матеріалів. Для порівняння інформаційний ресурс «Крыминформ», що підконтрольний міністру інформаційної політики Криму Д. Полонському і вважається найпопулярнішим та найцитованішим медіа в Криму, має в 3-4 рази меншу відвідуваність, аніж «Крим.Реалії». Зважаючи на ці невтішні для окупаційних ЗМІ показники, надалі схожу інформацію не оприлюднювали.

Керівник проєкту В. Притула водночас наголошує, що робота проєкту «Крим. Реалії» зазнає інформаційних атак не лише з боку окупантів: «Для окупаційної влади Криму ми чи українські націоналісти, чи американські шпигуни. А на материку підпадаємо під тиск частини суспільства, що ми начебто недостатньо патріотичні, не завжди правильно формулюємо - недостатньо вживаємо слово «окупаційний», наприклад. Дехто навіть публічно оголошував нам бойкот» ${ }^{17}$. У редакції проєкту «Крим.Реалії» зауважують, що у своїй роботі намагаються «шукати золоту середину», дотримуватися професійних стандартів і керуватися передовсім потребами кримської аудиторії отримати незалежну та правдиву інформацію.

Наприкінці 2017 р. Міністерство юстиції Росії заявило, що діяльність проєкту «Крим.Реалії» радіо «Свобода» може «зазнати обмежень», оскільки начебто підпадає під дію російського закону про обмеження для організацій-іноземних агентів.

Журналіст української редакції радіо «Свобода», колумніст та політичний оглядач В. Портников, оцінюючи такі дії Мін’юсту Росії, зауважив, що «за допомогою поправок в закон про «іноземних агентів» російське керівництво хоче легітимізувати не тільки своє право на брехню, але й своє право на окупацію і анексію» росіяни, як наголошує автор, почали вдавати, що проєкт «Крим.Реалії» жодного стосунку до української редакції радіо «Свобода» не має, що це суто російська проблема, оскільки проєкт діє самостійно або ж підпорядковується російській службі радіо «Свобода», яка, відповідно, висвітлює проблеми областей і регіонів Росії.

Постійні провокаційні дії з боку окупаційної влади щодо роботи проєкту «Крим.Реалії» стали за роки анексії вже звичною практикою. В останньому зі звітів Кримської правозахисної групи (КПГ), яка тісно співпрацює з проєктом «Крим. Реалії», сказано: «Моніторинг КПГ, здійснений у вересні, засвідчив, що мінімум у 10 населених пунктах північного Криму український радіосигнал повністю заблоковано. Ще у 9 населених пунктах сигнал заблоковано частково. Блокування відбувається шляхом увімкнення російських радіостанцій на українських частотах. Таким чином, російська влада блокує українське FM-мовлення на півострові, практично позбавивши громадян України доступу до інформації незалежних українських радіостанцій. Моніторинг блокування сайтів, який КПГ здійснила у вересні, зафіксував,

\footnotetext{
17 Зінченко-Апостолова, Л. (2017), «Журналісти «Крим.Реалї̈: Ми відчуваємо тиск - $i$ з боку украӥнського суспільства, і з боку окупаційної влади Криму», Detektor.Media, доступно за адресою URL: https://detector.media/infospace/article/128485/2017-07-31-zhurnalisti-krim-realii-mividchuvaemo-tisk-i-z-boku-ukrainskogo-suspilstva-i-z-boku-okupatsiinoi-vladi-krimu/ (дата перегляду 6 листопада 2019 р.).

${ }^{18}$ Портников, В. (2017), «Украйнський Крим і гра Кремля в «іноземних агентів», Detektor.Media, доступно за адресою URL: https://detector.media/withoutsection/article/132099/2017-11-19ukrainskii-krim-i-gra-kremlya-v-inozemnikh-agentiv/ (дата перегляду 6 листопада 2019 p.).
} 
що 10 кримських провайдерів у дев'яти містах повністю блокують 18 українських інформаційних сайтів і 2 соціальні мережі» ${ }^{19}$. До українських медіа, мовлення яких блокують окупанти, належить також і проєкт «Крим.Реалії».

25 березня 2018 р. в Києві в межах фестивалю документальних фільмів Docudays UA були представлені стрічки, авторами яких стали журналісти проєкту «Крим.Реалії». Це також один із напрямків, які розвиває редакція. У кожному з них використано відеоматеріали, зняті на окупованому півострові. Фільми «Крим. Нескорений», «Крим. Переможців не судять», «Микола Семена. Думки під забороною», «Непохитний Балух. Вирок», «Заборонене кохання: життя ЛГБТ-спільноти в Криму» викликали широкий резонанс та зацікавлення глядацької аудиторії. Їх демонстрували центральні українські телеканали. Вони стали черговою підставою для переслідування журналістів проєкту. Для прикладу, під час зйомок фільму про політв'язня Володимира Балуха, окрім постійного стеження, підконтрольна Росії кримська поліція склала протокол на знімальну групу та оштрафувала за «незаконне виконання журналістської діяльності на території Росії».

Щотижня проєкт готує дві телевізійні програми під назвою «Крим.Реалії» для загальнонаціональних та численних регіональних телеканалів. Їх також можна дивитися на You Tube-каналі «Крим.Реалії», що створений восени 2015 р. Програму «Крим.Реалії» також постійно транслюють міжнародний супутниковий телеканал «Настоящее время» та кабельні мережі 25 країн Східної Європи та Центральної Азії.

Хоча напрямки роботи «Крим.Реалії» розширюються, а обсяги інформації для аудиторії зростають, це лише продовжує ускладнювати роботу журналістів проєкту в окупованому Криму. Російська адміністрація та спецслужби, усвідомлюючи загрозу від поширення незалежної інформації, продовжують активно переслідувати буквально всіх, хто наважується співпрацювати з проєктом.

Проєкт «Крим.Реалії» української редакції радіо «Свобода» став першим прикладом ефективного інформаційного спротиву російській агресії, тоді як українська держава в умовах зради національних інтересів президентом та його оточенням i їхньої подальшої втечі перебувала в стані розгубленості і була неспроможна оперативно реагувати не лише на медійні, але й на військові виклики повзучої окупації.

Сьогодні умови, у яких доводиться жити кримцям і працювати журналістам проєкту, - це постійний стан пригніченості, підозр і страху, а також спостереження за тим, як півострів поступово перетворююється на суцільну військову базу Росії: «ідеології військового плацдарму сьогодні підпорядковані всі інші сфери життя в Криму - цивільна економіка, соціальна сфера, освіта та виховання дітей і молоді, права людини, інформаційний простір, національна політика» ${ }^{20}$.

У такій ситуації мовлення проєкту «Крим.Реалії» - це не лише доступ до правдивих новин, але й відчуття зв'язку з українською державою, цивілізованим світом, які бодай у такий спосіб дають зрозуміти, що не забувають кримців і що $є$ надія на повернення острова в майбутньому до складу України.

19 «Моніторинговий огляд ситуаџї з правами людини в Криму за вересень 2019» (2019), Кримська правозахисна група, доступно за адресою URL: https://crimeahrg.org/uk/monitoringovij-oglyadsituaczi\%d1\%97-z-pravami-lyudini-u-krimu-za-veresen-2019/ (дата перегляду 6 листопада 2019 р.).

${ }^{20}$ Гучакова, Т., Клименко, А. (2018), «Повернення радянського Криму», Український тиждень, №36 (560), c. 14. 
5. Результати і перспективи подальших досліджень. У статті простежено історію створення проєкту «Крим.Реалії» української редакції радіо «Свобода» як реакцію на російську окупацію півострова. Показано, як упродовж п'яти років роботи проєкт зумів стати окремою повноцінною конвергентною редакцією, що створює телепрограми, фільми, веде цілодобове радіомовлення, має власний популярний сайт, ефективно працює в соціальних мережах та на різних інтернет-платфомах.

Показано, що особливість проєкту «Крим.Реалії» полягає в тому, що він не лише був першим, але й залишається одним із найпопулярніших медіа, що ведуть мовлення на анексований півострів. А це свідчить про те, якою великою $є$ тут потреба в незалежній та правдивій інформації. Водночас така робота журналістів проєкту, їхніх помічників і симпатиків є постійною підставою для переслідувань 3 боку окупаційної адміністрації.

Вважаємо перспективним подальше вивчення роботи як проєкту «Крим.Реалії», що перебуває в постійному розвитку, так і створеного згодом українською редакцією радіо «Свобода» проєкту «Донбас.Реалії», а також перспективним $є$ порівняльний аналіз їхньої діяльності.

6. Висновки. Російська анексія Криму, незважаючи на роки відвертої пропагандистської підготовки і діяльності проросійської агентури на півострові, вразила світ своїм віроломством. Для проведення гібридної військової операції було вибрано момент, коли українська держава виявилася мілітарно й інформаційно неготовою відстоювати свою територію. Українська редакція радіо «Свобода», спираючись на досвід тривалої боротьби з радянською пропагандою в роки холодної війни, змогла продемонструвати найбільшу адекватність щодо викликів, які постали з початком окупації.

Створення проєкту «Крим.Реалії» стало одним із підтверджень, що міжнародна спільнота не сприймає акту війської агресії щодо України, не визнає результатів псевдореферендуму в Криму і готова надавати об’єктивну інформацію про події на півострові. Проєкт діє на противагу офіційній пропаганді російських ЗМI та місцевих медіа, які виступають рупором окупантів та кримської маріонеткової влади. «Крим.Реалії», перебуваючи поза цензурними обмеженнями, які тяжіють над російськими 3МI, має змогу готувати цілком незалежні та об'єктивні програми та новини. Це є головною підставою, що контенту, який виробляють журналісти проєкту, довіряють кримці, незважаючи на те що вони перебувають під постійним інформаційним пресом російських медіа. Важливим чинником $є$ також те, що «Крим.Реалії» звертається до кримської аудиторії українською, кримськотатарською та російською мовами, тож, відповідно, доступний у трьох оригінальних версіях сайтів і веде телета радіопрограми трьома мовами. Це гарантує доступ як зацікавленій аудиторії, так і передовсім кримцям до матеріалів проєкту рідною мовою.

Незважаючи на переслідування та заборони з боку окупаційної влади, журналісти «Крим.Реалії», виконуючи свою роботу, не лише повідомляють правдиву інформацію, але також тим самим утримують кримців в українському інформаційному полі, даючи надію на повернення півострова до складу української держави. Цей проєкт як відповідь на гібридну війну проти незалежної держави, без сумніву, $\epsilon$ прикладом не лише протидії агресорові, але й початком інформаційної деокупації анексованої території. 


\section{СПИСОК ЛІТЕРАТУРИ}

1. Гучакова, Т., Клименко, А. (2018), «Повернення радянського Криму», Український тиждень, № 36 (560), с. 13-17.

2. Зінченко-Апостолова, Л. (2017), «Журналісти «Крим.Реалії»: Ми відчуваємо тискіз боку украӥнського суспільства, із боку окупаиійної влади Криму», Detektor.Media, доступно за адресою URL: https://detector.media/infospace/article/128485/2017-07-31zhurnalisti-krim-realii-mi-vidchuvaemo-tisk-i-z-boku-ukrainskogo-suspilstva-i-z-bokuokupatsiinoi-vladi-krimu/ (дата перегляду 6 листопада 2019 p.).

3. «3 квітня в окупованому Росією Криму можна буде слухати чотири украӥнські padiocтаниіï», (2017), Detektor.Media, доступно за адресою URL: https://detector. media/infospace/article/123794/2017-03-05-z-kvitnya-v-okupovanomu-rosieyu-krimumozhna-bude-slukhati-chotiri-ukrainski-radiostantsii/ (дата перегляду 6 листопада 2019 p.).

4. «Константинов про «Крим.Реалії». Це вороги, які хочуть зробити боляче» (2016), Українська правда, доступно за адресою URL: https://www.pravda.com.ua/ news/2016/04/20/7106176/ (дата перегляду 6 листопада 2019 р.).

5. Луканов, Ю. (2018), Пресувальна машина: як Росія знищувала свободу слова в Криму, Київ, КБЦ, 176 с.

6. «Моніторинговий огляд ситуації з правами людини в Криму за вересень 2019» (2019), Кримська правозахисна група, доступно за адресою URL: https://crimeahrg. org/uk/monitoringovij-oglyad-situaczi\%d1\%97-z-pravami-lyudini-u-krimu-zaveresen-2019/ (дата перегляду 6 листопада 2019 р.).

7. Портников, В. (2017), «Украӥнський Крим і гра Кремля в «іноземних агентів», Detektor.Media, доступно за адресою URL: https://detector.media/withoutsection/ article/132099/2017-11-19-ukrainskii-krim-i-gra-kremlya-v-inozemnikh-agentiv/ (дата перегляду 6 листопада 2019 р.).

8. Почепцов, Г. (2019), (Дез)информация, Киев, Паливода А. В., 248 с.

9. «Прокуратура окупованого Криму зібралася повністю заблокувати сайт «Крим.Реалї̈», (2016), Тиждень.uа, доступно за адресою URL: https://tyzhden.ua/ News/163403 (дата перегляду 6 листопада 2019 р.).

10. Толокольнікова, К. (2016), «Володимир Притула: Жоден кримський журналіст не пише для «Крым.Реалии» під власним іменем», Detektor.Media, доступно за адресою URL: https://detector.media/community/article/114325/2016-04-14-volodimirpritula-zhoden-krimskii-zhurnalist-ne-pishe-dlya-krym-realii-pid-vlasnim-imenem/ (дата перегляду 6 листопада 2019 р.).

11. Холоденко, О. (2019), Мені погано, коли мовчу. Журналістика незалежсної України: інтерв'ю відомих медійників, Київ, Паливода А.В., 512 с.

\section{REFERENCES}

1. Huchakova, T., Klymenko, A. (2018) «The Return of the Soviet Crimea», The Ukrainian week, № 36 (560), p. 13-17.

2. Zinchenko-Apostolova, L. (2017), «The Journalists «Crimea. Realities»: We feel the pressure from - Ukrainian society and from the occupational government of Crimea», URL: $\quad \underline{\text { https://detector.media/infospace/article/128485/2017-07-31-zhurnalisti-krim- }}$ 
realii-mi-vidchuvaemo-tisk-i-z-boku-ukrainskogo-suspilstva-i-z-boku-okupatsiinoivladi-krimu/

3. «Starting in April, four Ukrainian radio stations will be available to listen at Russiaoccupied Crimea», (2017), Detektor.Media, URL: https://detector.media/infospace/ article/123794/2017-03-05-z-kvitnya-v-okupovanomu-rosieyu-krimu-mozhna-budeslukhati-chotiri-ukrainski-radiostantsii/(дата перегляду 6 листопада 2019 р.).

4. «Konstantinov about «Crimea. Reality». These are the enemies that want to hurt» (2016), The Ukrainian pravda, URL: https://www.pravda.com.ua/news/2016/04/20/7106176/

5. Lukanov, Y. (2018), Pressing machine: how Russia destroyed the freedom of speech in Crimea, Kyiv, KBC, $176 \mathrm{p}$.

6. «Monitoring of the Human Rights Situation in Crimea in September 2019» (2019), Crimean human rights group, URL: https://crimeahrg.org/uk/monitoringovij-oglyadsituaczi\%d1\%97-z-pravami-lyudini-u-krimu-za-veresen-2019/

7. Portnikov, V. (2017), «Ukrainian Crimea and the Kremlin's game of «foreign agents», Detektor.Media, URL: https://detector.media/withoutsection/article/132099/2017-11-19ukrainskii-krim-i-gra-kremlya-v-inozemnikh-agentiv/

8. Pochjepchov, H. (2019), (Dis)information, Kyiv, Palyvoda A. V., 248 p.

9. «The prosecutor's office of the occupied Crimea is going to completely block the site "Crimea.Realities"》, (2016), Tyzhden.ua, URL: https://tyzhden.ua/News/163403

10. Tolokolnikova, K. (2016), «Volodymyr Prytula: No Crimean journalist writes for "Crimea. Reality" under his own name», Detektor.Media, URL: https://detector.media/ community/article/114325/2016-04-14-volodimir-pritula-zhoden-krimskii-zhurnalistne-pishe-dlya-krym-realii-pid-vlasnim-imenem/

11. Cholodenko, O. V. (2019), "I feel bad when I keep quie't. Independent Ukrainian journalism: Interviews by famous media representatives», Kyiv, Palyvoda A. V., 512 p. 


\title{
THE PROJECT «CRIMEA. REALITIES» OF THE UKRAINIAN EDITORIAL OFFICE OF RADIO LIBERTY: THE INFORMATION RESISTANCE TO THE RUSSIAN ANNEXATION OF THE PENINSULA
}

\author{
Ivan Tsyperdiuk \\ Private institution of higher education «King Danylo University», \\ Y. Konovaltsia str., 35, 76018, Ivano-Frankivsk, Ukraine \\ e-mail: zdjuk@ukr.net \\ https://orcid.org/0000-0003-0940-5066
}

The purpose of the article is to show the importance of creating the "Crimea. Reality" project of the Ukrainian editorial office of Radio Liberty in order to disseminate impartial information about the real situation on the peninsula, to document the criminal actions of the occupying power and to maintain continuous media communication with the population of the occupied Crimea.

The methods of analysis and synthesis, as well as monitoring of publications by topic, were used for scientific exploration. The generalization and consideration of all the circumstances and facts that accompanied to the creation of the project «Crimea. Reality» of the Ukrainian editorial office of Radio Liberty, based on the above methods, made it possible, to understand the timeliness and importance of such step in the conditions of the Russian occupation of the peninsula. The article traces the history of the creation of the "Crimea. Reality" project as the reaction to the Russian occupation of the peninsula.

It was demonstrated that the "Crimea. Reality" project was one of the most popular media that was broadcasting on the annexed peninsula. This shows the great need for objective information on the peninsula. At the same time, such work of project journalists is a constant basis for persecution by the occupation administration. Russia's hybrid annexation of Crimea, which led to the creation of the editorial office of «Crimea Reality» and its work, is of scientific interest for further research, because the media project is in constant development. Following this, the Ukrainian editorial office of Radio Liberty initiated the creation of the separate "Donbas. Reality" project. We also consider a comparative analysis of the history and activities of these two projects, which may result in separate scientific exploration.

Key words: "Crimea. Reality", the Ukrainian editorial office of Radio Liberty, annexation, the Russian propaganda, occupation. 